\title{
Establishment of Cephalic Index Using Cranial Parameters by Computed Tomography in a Sampled North Indian Population
}

Sachin Khanduri ${ }^{1}$, Saif Malik ${ }^{2}$, Nazia Khan ${ }^{2}$, Yunus D. Patel ${ }^{2}$, Asif Khan ${ }^{2}$, Harleen Chawla ${ }^{3}$, Vishwesh Singh $^{2}$, Ashok Gupta ${ }^{2}$, Juned Shaikh ${ }^{2}$, Saim Siddiqui ${ }^{2}$

1. Radiology, Era's Lucknow Medical College and Hospital, Lucknow, IND 2. Radiodiagnosis, Era's Lucknow Medical College and Hospital, Lucknow, IND 3. Radiodiagnosis, Era's Lucknow Medical College and Hospital, Lucknow, IND

Corresponding author: Saif Malik, saifmalik77@icloud.com

\section{Abstract}

Background: Cephalic index (CI) also called cranial index is the ratio of maximum breadth to a maximum length of head. The purpose of the study was to study anthropometry of cranial parameters using the computed tomography (CT) scans to establish the CI of the sampled population in North India.

Materials and methods: The cross-sectional study was carried on the subjects of age group ranging from 6 to 95 years of either sex (total 1000 subjects; 540 male and 460 female) in the radio-diagnosis department of Era's Medical College Lucknow, UP, India. The measurement of maximum cranial breadth (MCB) and maximum cranial length (MCL) were taken on a CT scan machine and recorded for analysis. When associating the measures of precision for different subgroups, a one-way analysis of variance (ANOVA) was used for modest and efficient errors. Multivariate logistic regression analysis was used to identify factors affecting the CI estimation like age, interzygomatic length (IZL), orbital length (OL), MCB, and MCL.

Result: Out of 1000 studied subjects, the majority 234 (23.4\%) of the subjects belong to the 21-30 years age group. MCB of heads and MCL of heads in different ages and on applying the one-way ANOVA association was statistically significant and CI was statistically insignificant. Pearson correlation between the $\mathrm{CI}$ and other parameters like age, MCB of heads, and MCL of heads, and a statistically significant correlation was seen with each other. Dolichocephalic types of the skull are found more in male subjects, and brachycephalic type of skull is more common in female subjects.

Conclusion: The average $\mathrm{CI}$ of our study was $76.67 \pm 3.18$. This shows that northern India's dominant head shape, especially in the Lucknow region, was dolichocephaly. Thus, the CT scan is proven an essential modality in the assessment of cranial parameters in anthropometry.

Review began 05/26/2021 Review ended 05/26/2021 Published 06/03/2021

\section{○ Copyright 2021}

Khanduri et al. This is an open access article distributed under the terms of the Creative Commons Attribution License CC-BY 4.0., which permits unrestricted use, distribution, and reproduction in any medium, provided the original author and source are credited.
Categories: Radiology, Anatomy

Keywords: anthropometry, cranial index, computed tomography, cephalic index, max cranial breadth of heads, max cranial length of heads, mesocephalic, dolicocephalic

\section{Introduction}

Cephalic index (CI), also known as the index of breadth or cranial index, is one of the major parameters that help to distinguish between the different races of humans. The CI was described by a Swedish professor (1796-1860) and was first used in physical anthropology to categorize remains of ancient humans found in Europe [1].

The dimensions of the human body are affected by biological, ecological, geographical, sex, racial, and age factors [2]. The CI is measured as the breadth of the skull multiplied by 100 and divided by length. CI is classified into three broad categories: dolichocephalic (less than 75), mesaticephalic (75 to 80), and brachycephalic (greater than 80). Australian and native Southern Africans are dolichocephalics, Chinese and European skulls are mesaticephalic, and Andaman Islanders and Mongolians have brachycephalic skulls $[3,4]$.

Currently, CI is commonly used to portray individuals' appearances and for roughly calculating the age of the fetuses for obstetrical and legal reasons. So it can be widely used in various investigations in forensic labs. Comparison of changes in CI among offspring, parents, and siblings may give a hint to the genetic transmission of the inherited characters. CI is the jargon used in anthropology for having an easy identifying module or the numerical to differentiate the given individual, either into sex or race or even as the identity of the individual [5].

Cephalometric examination relies upon the cephalometric radiography to examine connections in the middle of delicate and hard tissue points of interest and may be utilized to investigate facial development 
differences from norm preceding treatment, amidst treatment to evaluate progress or at the end of treatment to determine that the objectives of the treatment have been met [6]. The lateral cephalometric radiograph is a radiograph of the head brought with an X-ray beam opposite to the patient's sagittal plane $[6,7]$. The regular position of the head is a systematized introduction of the head which is reproducible for each person and is used as a process for examination of the dentofacial morphology.

More recently, computed tomography (CT) has permitted complete imaging of the whole craniofacial complex. This technology is enhanced further by the computer software that allows three-dimensional (3D) reconstructions of the CT slices, allowing the life-like appearance of the face and skull for measuring purposes. CT has provided the latest tools for medical investigation and has been used widely for pre and post-operative imaging when assessing patients with craniofacial abnormalities [8].

Regarding the effect of ethnic, racial, and geographical factors on the head dimensions, the present study was performed to find the CI of the adult population, to determine the dominant head type and sexual dimorphism in Northern Indian adults populations of age group >18 years of Lucknow. The observations and findings of the present study will provide a platform for similar cephalometric studies done on various communities, castes, races of particular geographic zones.

\section{Materials And Methods}

The present cross-sectional study was performed in the Department of Radio-Diagnosis, Era's Medical College, Lucknow, UP, India. One thousand subjects of different age groups from 6 to 95 years of both sexes were selected. The subjects chosen were apparently healthy and without any visible spinal or cranial deformity. Any subject with congenital or acquired cranial, spinal, or bone deformity, i.e., scoliosis, kyphosis, etc., were excluded. The CT scans for facial bones were performed on a 384 slice Dual Energy CT scanner (Somaton Force, Seimens Healthcare, Erlangen, Germany) and all images were post-processed on a workstation using Synovia software (Synovia Solutions, Fort Worth, TX) that allowed analysis of images using three material decompositions. Examinations were evaluated by an experienced radiologist.

The formula used to calculate the CI:

$\mathrm{CI}=\left[\right.$ Maximum Cranial Breadth $(\mathrm{MCB}) /$ Maximum Cranial Length $(\mathrm{MCL}){ }^{*} 100$

On the basis of the CI, skulls were classified as “According to Modi's Medical Jurisprudence and Toxicology, the skulls having CI between 70 and 74.9 are called dolichocephalic or long headed" $[9,10]$. This type is common among Aborigines and pure Aryans. Skulls having CI from 75-79.9 are grouped under mesocephalic and are common features of Europeans and Chinese. The more CI from 80 to 84.9 is called brachycephalic or short-headed. The Mongolian race is an example of brachycephalic heads [11].

\section{Statistical analysis}

Statistical analysis was done by using the Statistical Package for Social Sciences (SPSS-23, IBM Corp., Armonk, NY) program. Data were expressed in the form of frequency in percentage and value in mean and standard deviation. When associating the measures of precision for different subgroups, a one-way analysis of variance (ANOVA) was used for the modest and efficient errors. Multivariate logistic regression analysis was used to identify factors affecting the CI estimation like age, interzygomatic line (IZL), orbital length $(\mathrm{OL})$, maximum breadth of heads, and head's maximum length. A p-value of $<0.05$ was used as the criterion of statistical significance.

\section{Results}

Out of the total 1000 studied subjects, the majority 234 (23.4\%) of subjects belonged to the age group 21-30 years and the mean age of the total studied subjects was $43.43 \pm 20.71$ years (range 6-95 years; Table 1). 


\section{Cureus}

\begin{tabular}{|c|c|c|c|}
\hline \multirow{2}{*}{ Age group (years) } & \multicolumn{2}{|l|}{ Sex } & \multirow{2}{*}{ Total } \\
\hline & Male $(n=540)$ & Female $(n=460)$ & \\
\hline$\leq 20$ & 74 (13.7\%) & 68 (14.8\%) & 142 (14.2\%) \\
\hline $21-30$ & $130(24.1 \%)$ & $104(22.6 \%)$ & 234 (23.4\%) \\
\hline $31-40$ & $60(11.1 \%)$ & $72(15.7 \%)$ & $132(13.2 \%)$ \\
\hline $41-50$ & $56(10.4 \%)$ & 60 (13.0\%) & 116 (11.6\%) \\
\hline 51-60 & $64(11.9 \%)$ & $56(12.2 \%)$ & $120(12.0 \%)$ \\
\hline $61-70$ & $80(14.8 \%)$ & 60 (13.0\%) & 140 (14.0\%) \\
\hline $71-80$ & 64 (11.9\%) & 32 (7.0\%) & 96 (9.6\%) \\
\hline$>80$ & $12(2.2 \%)$ & $8(1.7 \%)$ & $20(2.0 \%)$ \\
\hline Mean age (mean $\pm S D$ ) years & $44.37 \pm 21.16$ & $42.32 \pm 20.16$ & $43.43 \pm 20.71$ \\
\hline
\end{tabular}

TABLE 1: Age and sex distribution of the studied cases

Male subjects (54.0\%) were dominant over females subjects (46.0\%; Table 1 ). The MCL of subjects was $17.50 \pm 0.57 \mathrm{~mm}$, mean MCB of heads was $13.40 \pm 0.39 \mathrm{~mm}$, mean IZL was $12.17 \pm 0.49 \mathrm{~mm}$, OL was $4.10 \pm 0.19$, and mean CI was $76.67 \pm 3.18$ (Table 2 ).

\begin{tabular}{|c|c|c|c|c|}
\hline \multirow{2}{*}{ Variables } & \multirow{2}{*}{ Total $(n=1000)$} & \multicolumn{2}{|l|}{ Sex } & \multirow{2}{*}{ P-value } \\
\hline & & Male $(n=540)$ & Female $(n=460)$ & \\
\hline Maximum cranial length (mm) & $17.50 \pm 0.57$ & $17.69 \pm 0.46$ & $17.28 \pm 0.60$ & $<0.001$ \\
\hline Maximum cranial breadth (mm) & $13.40 \pm 0.39$ & $13.36 \pm 0.38$ & $13.45 \pm 0.38$ & $<0.001$ \\
\hline Interzygomatic length (mm) & $12.17 \pm 0.49$ & $12.34 \pm 0.47$ & $11.97 \pm 0.42$ & $<0.001$ \\
\hline Orbital length (mm) & $4.10 \pm 0.19$ & $4.16 \pm 0.19$ & $4.04 \pm 0.17$ & $<0.001$ \\
\hline Cephalic index & $76.67 \pm 3.18$ & $75.59 \pm 2.64$ & $77.94 \pm 3.30$ & $<0.001$ \\
\hline
\end{tabular}

TABLE 2: Distribution of maximum cranial length, maximum cranial breadth, interzygomatic line, orbital length, and cephalic index in both sex groups

The distribution of MCL, mean MCB, mean IZL, OL, and mean CI in different gestational ages was statistically significant $(\mathrm{p}<0.05$; Table 3$)$. 


\section{Cureus}

\begin{tabular}{|c|c|c|c|c|c|c|}
\hline Age group (years) & $\mathbf{N}$ & MCL & МСВ & IZL & OL & $\mathrm{Cl}$ \\
\hline$\leq 20$ & 142 & $17.59 \pm 0.45$ & $13.40 \pm 0.33$ & $12.21 \pm 0.51$ & $4.08 \pm 0.16$ & $76.27 \pm 2.97$ \\
\hline $21-30$ & 234 & $17.50 \pm 0.57$ & $13.50 \pm 0.37$ & $12.19 \pm 0.47$ & $4.11 \pm 0.19$ & $77.25 \pm 3.18$ \\
\hline $31-40$ & 132 & $17.62 \pm 0.44$ & $13.39 \pm 0.35$ & $12.04 \pm 0.49$ & $4.09 \pm 0.16$ & $76.10 \pm 3.34$ \\
\hline $41-50$ & 116 & $17.45 \pm 0.46$ & $13.39 \pm 0.35$ & $12.13 \pm 0.48$ & $4.10 \pm 0.19$ & $76.79 \pm 2.99$ \\
\hline $51-60$ & 120 & $17.51 \pm 0.66$ & $13.42 \pm 0.27$ & $12.02 \pm 0.46$ & $4.04 \pm 0.17$ & $76.73 \pm 3.15$ \\
\hline $61-70$ & 140 & $17.43 \pm 0.68$ & $13.30 \pm 0.34$ & $12.29 \pm 0.46$ & $4.16 \pm 0.21$ & $76.42 \pm 3.02$ \\
\hline $71-80$ & 96 & $17.43 \pm 0.55$ & $13.44 \pm 0.51$ & $12.28 \pm 0.51$ & $4.11 \pm 0.20$ & $77.19 \pm 3.61$ \\
\hline$>80$ & 20 & $17.20 \pm 0.89$ & $12.84 \pm 0.72$ & $12.26 \pm 0.39$ & $4.21 \pm 0.12$ & $74.65 \pm 2.14$ \\
\hline \multirow{2}{*}{ One way ANOVA test } & F-value & 2.742 & 10.729 & 5.440 & 5.683 & 3.769 \\
\hline & P-value & 0.008 & $<0.001$ & $<0.001$ & $<0.001$ & $<0.001$ \\
\hline
\end{tabular}

TABLE 3: Distribution of maximum cranial length, maximum cranial breadth, interzygomatic length, orbital length, and cephalic index in different age groups

The statistically significant association was observed among MCL $(r=-0.722 ; \mathrm{P}<0.001), \mathrm{MCB}(\mathrm{r}=0.616$; $\mathrm{P}<0.001)$, IZL ( $\mathrm{r}=-0.262 ; \mathrm{P}<0.001)$, and $\mathrm{OL}(\mathrm{r}=-0.191 ; \mathrm{P}<0.001)$ with $\mathrm{CI}$ on applying the Pearson correlation $(\mathrm{p}<0.05)$; while statistically insignificant correlation was observed only age with $\mathrm{CI}(\mathrm{r}=-0.018$; $\mathrm{P}>0.05$; Table 4).

\begin{tabular}{|c|c|c|c|c|c|c|}
\hline & & Age & MCL & МСВ & IZL & OL \\
\hline \multirow{2}{*}{$\mathrm{Cl}$} & Pearson correlation & -0.018 & $-0.722^{*}$ & $0.616^{\star}$ & $-0.262^{*}$ & $-0.191^{\star}$ \\
\hline & Sig. (two-tailed) & 0.568 & 0.000 & 0.000 & 0.000 & 0.000 \\
\hline
\end{tabular}

\section{TABLE 4: Pearson correlation}

${ }^{*}$ Correlation is significant at 0.01 level (two-tailed).

The overall $47.2 \%$ study population shows the dolichocephalic (long head) in our study (Table 5).

\begin{tabular}{|c|c|c|}
\hline Skull Shapes & Frequency $(n=1000)$ & Percentage (\%) \\
\hline Hyper dolichocephalic & 4 & $0.4 \%$ \\
\hline Dolichocephalic & 472 & $47.2 \%$ \\
\hline Mesocephalic & 304 & $30.4 \%$ \\
\hline Brachycephalic & 220 & $22.0 \%$ \\
\hline
\end{tabular}

TABLE 5: Distribution of the different skull shapes obtained in the study population

Dolichocephalic and brachycephalic type of skull was found more in 31-60 years age, and mesocephalic type of skull was more in $\leqslant 30$ years age (Table 6). 


\section{Cureus}

\begin{tabular}{|c|c|c|c|c|}
\hline \multirow{2}{*}{ Cl group } & \multicolumn{3}{|c|}{ Age group (years) } & \multirow{2}{*}{ P-value } \\
\hline & $\leq 30(n=376)$ & $31-60(n=368)$ & $>60(n=256)$ & \\
\hline Hyper dolichocephalic & $0(0.0 \%)$ & $4(1.1 \%)$ & $0(0.0 \%)$ & \multirow{4}{*}{0.021} \\
\hline Dolichocephalic & 168 (44.7\%) & 188 (51.1\%) & 116 (45.3\%) & \\
\hline Mesocephalic & 124 (33.0\%) & $92(25.0 \%)$ & $88(34.4 \%)$ & \\
\hline Brachycephalic & $84(22.3 \%)$ & $84(22.8 \%)$ & $52(20.3 \%)$ & \\
\hline
\end{tabular}

TABLE 6: Age-wise distribution of study cases based on cephalic index and type of skull

While dolichocephalic (Figure 1) and mesocephalic (Figure 2) type of skull was found more in male subjects, and brachycephalic (Figure 3) type of skull was more in female subjects (Table 7).

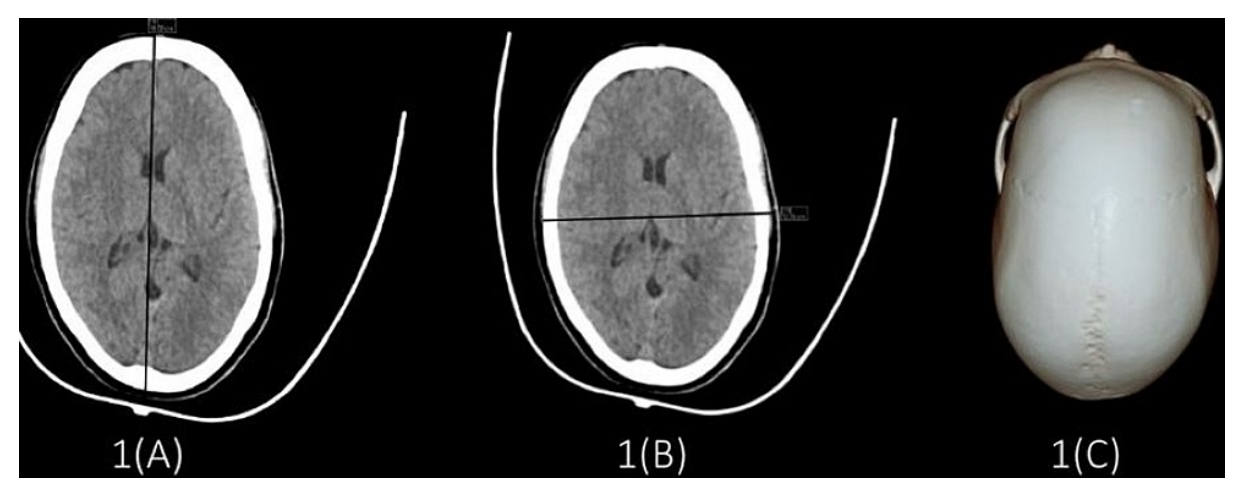

FIGURE 1: Images showing dolichocephalic skull

(A) Maximum cranial length $=18.64 \mathrm{~cm}$; (B) maximum cranial breadth $=13.21 \mathrm{~cm}$; (C) cephalic index $=70.86$.

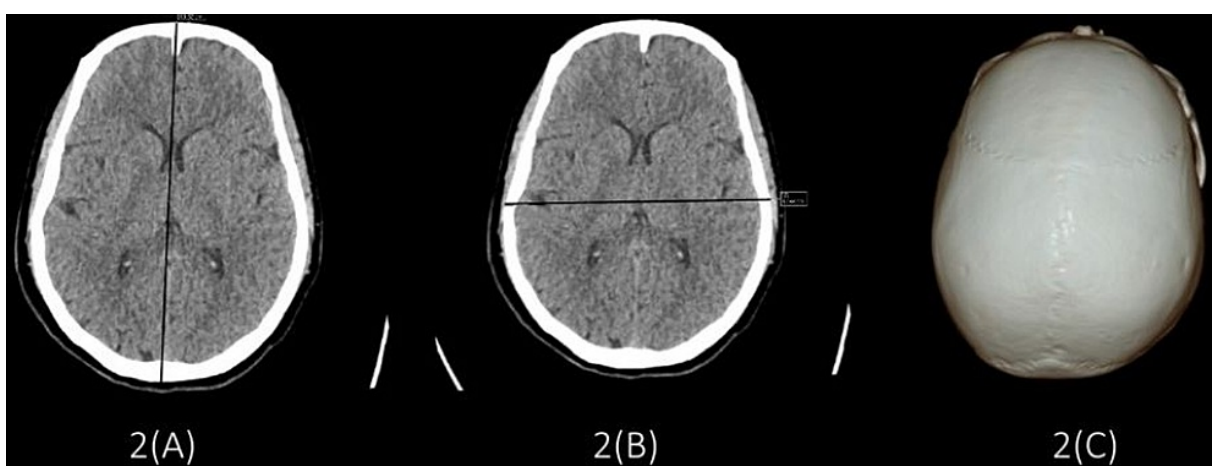

FIGURE 2: Images showing mesocephalic skull

(A) Maximum cranial length $=17.63 \mathrm{~cm}$; (B) maximum cranial breadth $=13.81 \mathrm{~cm}$; (C) cephalic index $=78.33$. 


\section{Cureus}

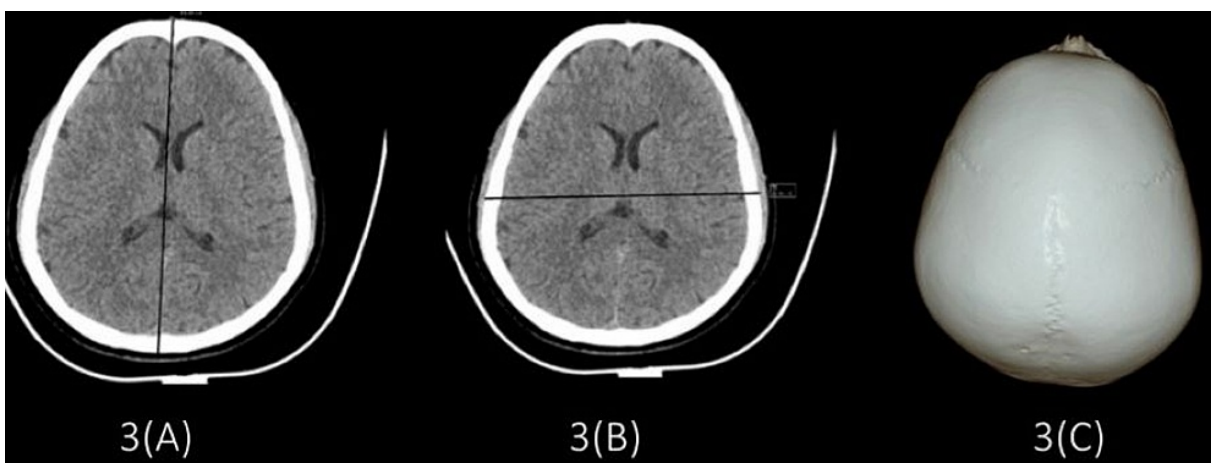

FIGURE 3: Images showing brachycephalic skull

(A) Maximum cranial length $=16.52 \mathrm{~cm}$; (B) maximum cranial breadth $=13.86 \mathrm{~cm}$; (C) cephalic index $=83.89$.

\begin{tabular}{|c|c|c|c|}
\hline \multirow{2}{*}{ Cephalic index group } & \multicolumn{2}{|l|}{ Sex } & \multirow{2}{*}{ P value } \\
\hline & Male $(n=540)$ & Female (n=460) & \\
\hline Hyper dolichocephalic & $4(0.7 \%)$ & $0(0.0 \%)$ & \multirow{4}{*}{$<0.001$} \\
\hline Dolichocephalic & $316(58.5 \%)$ & 156 (33.9\%) & \\
\hline Mesocephalic & $196(36.3 \%)$ & $108(23.5 \%)$ & \\
\hline Brachycephalic & $24(4.4 \%)$ & $196(42.6 \%)$ & \\
\hline
\end{tabular}

TABLE 7: Sex wise distribution of study cases based on cephalic index and type of skull

The distribution of MCL, MCB, IZL (Figure 4), OL (Figure 5), and mean CI in different age groups was statistically significant $(\mathrm{p}<0.05)$. 


\section{Cureus}

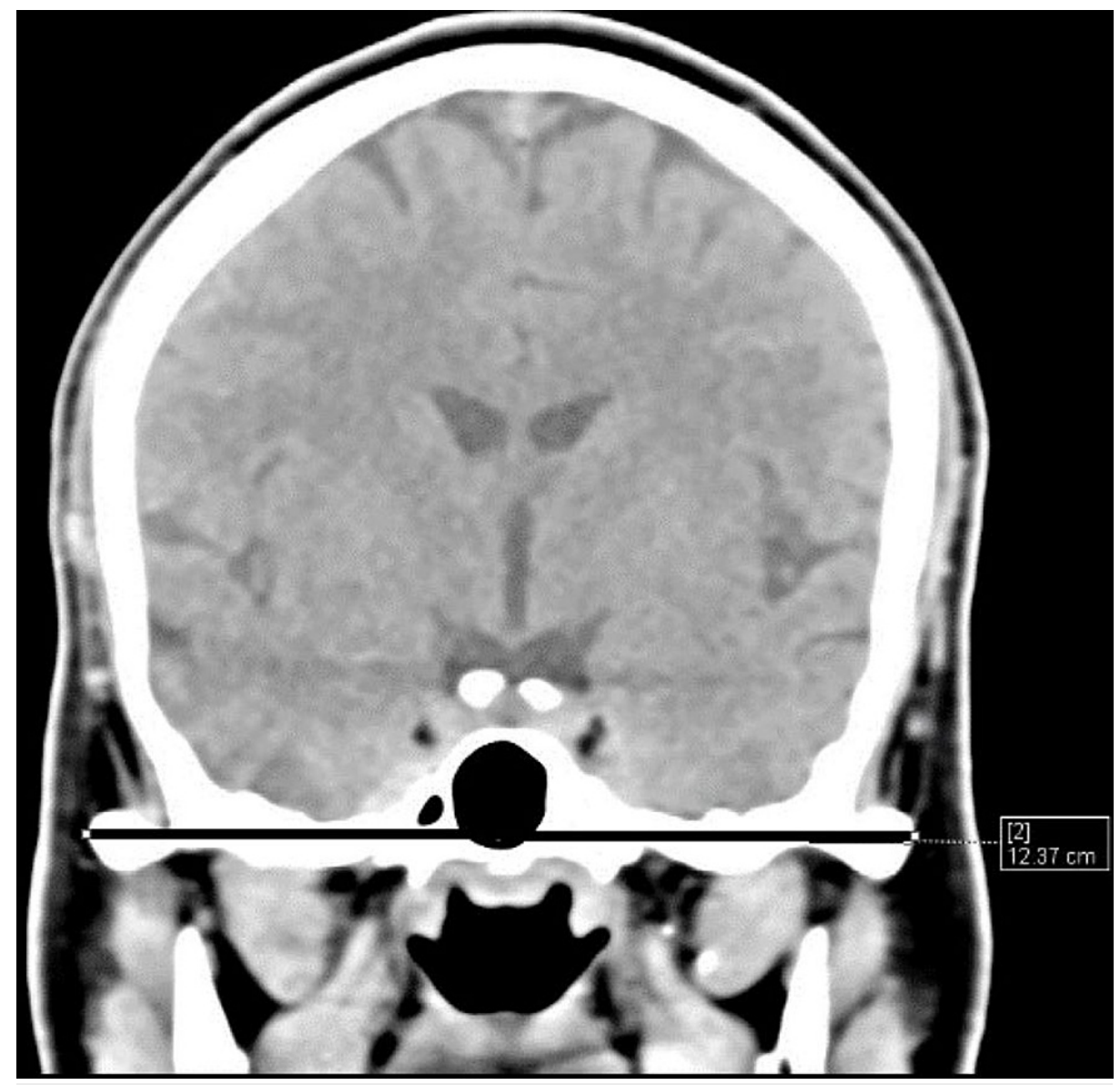

FIGURE 4: Interzygomatic length 


\section{Cureus}

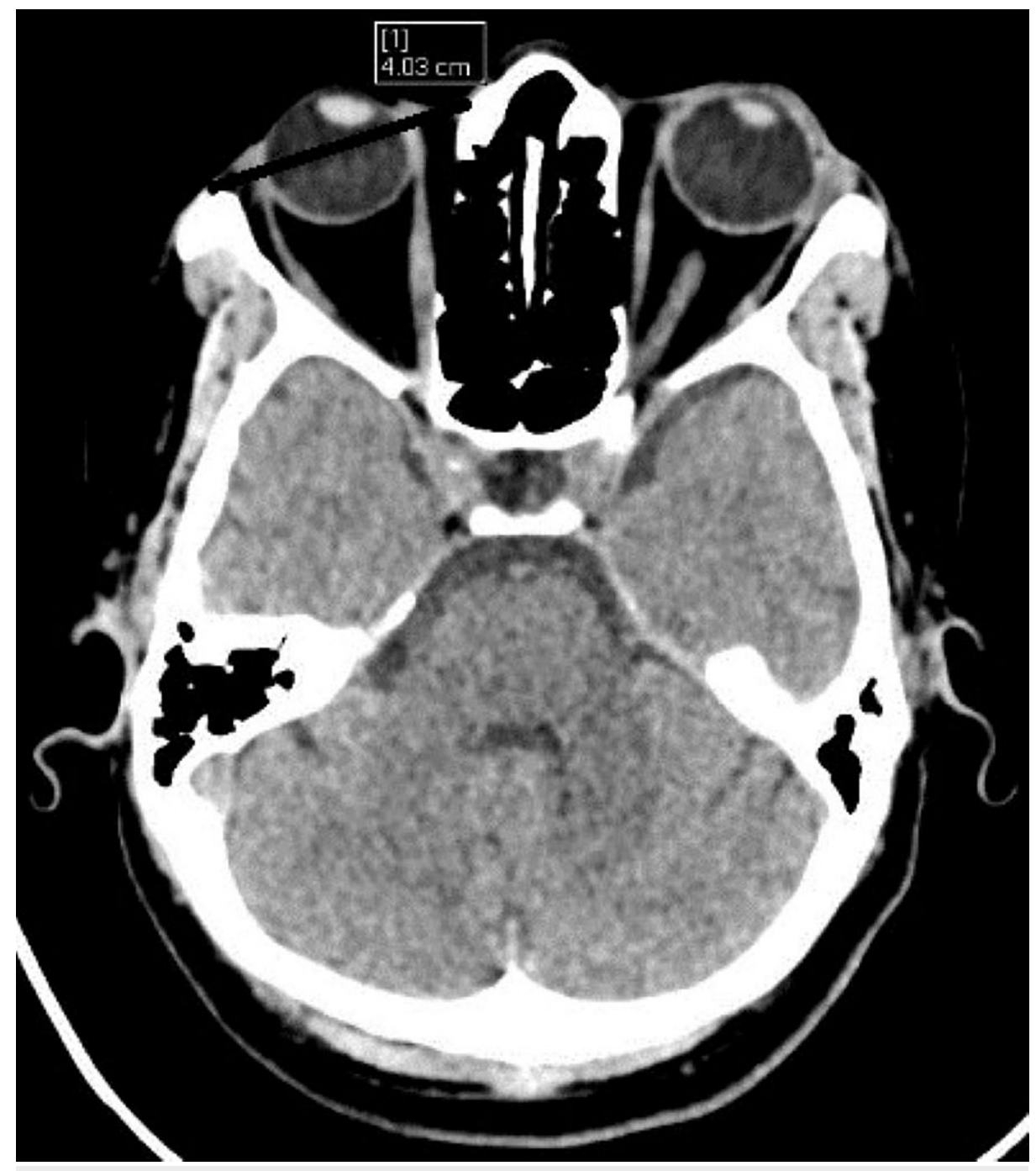

FIGURE 5: Orbital length

\section{Discussion}

Craniofacial anthropometry is imperative in assessing facial trauma, identification of inherited deformity, defects, and diagnosing different diseases. It is essential to have indigenous data of these constraints since these values reflect the possibly different shapes of craniofacial development subsequent from ethnic, racial, and sexual differences [12].

There are different racial groups including Blacks, Asians, and Whites, and their differences are based on physical characteristics. On the other hand, there are serious genetic differences among different races. It is recognized that using a standard for the craniofacial structures is not suitable when building treatment and diagnostic planning decisions for patients from a diverse ethnic background.

The $\mathrm{CI}$ is an assessment scale to measure the skull size. CI rating is achieved by multiplying the maximum width of the head by 100 and dividing that whole number by the maximum length of the head. It has been planned as a discriminating parameter to identify variations in the growth of the head. Its evaluations when the calculated index is above $\pm 2 \mathrm{SD}$ from the mean. The analysis of the CI states another aspect of development and growth of the skull, likewise allows critical assessment of unusually small or large heads. Also, the $\mathrm{CI}$ indirectly expresses the cranial capacity that is used indirectly to reveal the volume of the brain and predict mental ability [13]. Additionally, no research has been carried out in open literature using CT scans to produce normative reference data. Therefore, this study aimed to utilize CT scans to quantify the differences in craniofacial morphology of North Indians with well-known published data for other populations and observe whether the differences change with age or gender.

The socio-demographic characteristics including the age and sex obtained from the present study (Table 1) were taken into consideration with respect to the cranial dimensions or parameters of the North India sampled population. On the gender distribution, results of our study showed no significant difference 
between females and males which corroborates similar work done by Ekizoglu et al. [14], on the evaluation of gender in the modern Turkish population through the cranial CT anthropometric parameters, and Paulinus et al. [15], also observed the same by cranial CT-anthropometric parameters over Nigerians residing in Calabar.

We performed a cross-sectional study on 1000 subjects. Akinbami [16] performed a cross-sectional study on the 700 subjects; Singh and Purkit [17] conducted a cross-sectional study on the 200 subjects while Paulinus et al. [15], did a retrospective and prospective study of over 200 subjects. The collection of data offered by our study probably covers the most extensive age range with a large number of subjects in each gender and age group. The results of our study indicated that adult males had higher values than adult females.

In this study, mainstream subjects belonged to the age group 21-30 years, i.e., 234 (23.4\%) and the mean age of the total studied subjects was $43.43 \pm 20.71$ years (range 6-95 years). In our study, male subjects $54.0 \%$ were dominant over females subjects (46.0\%; Table 1). The MCL of subjects was $17.50 \pm 0.57 \mathrm{~mm}$, mean MCB of heads was $13.40 \pm 0.39 \mathrm{~mm}$, mean IZL was $12.17 \pm 0.49 \mathrm{~mm}$, and OL was $4.10 \pm 0.19$. The distribution of MCL, mean MCB, mean IZL, OL, and mean CI in different ages was statistically significant ( $\mathrm{p}<0.05$; Table 3).

We observed the mean $\mathrm{CI}$ of the male was $75.59 \pm 2.64$. This finding was slightly lower than the studies conducted by Singh and Purkit [17] and Mishra et al. [18]. Singh and Purkit [17] reported the mean CI of males was 77.71 \pm 4.91 , and Mishra et al. [18] reported 75.84 mean CI in males. Another Indian study from the Manipal region reported 77.92 mean CI in males [19] and Shah and Jadav [20] reported that CI's value was 80.42 in Gujrati males. The mean CI of females in this study was $77.94 \pm 3.30$. This finding was also lower than the research done by Singh and Purkit [17] who reported that females' mean CI was $79.35 \pm 5.72$. A study on resident Fars group with 85.0 in the north of Iran and Turkman group 82.8 in North of Iran [21], Shah and Jadhav [20], from India with 81.20, Manipal females with 80.85 [19]. But higher than the study in Tehran - the center of Iran with 75, Igbo (76.83) tribes community [22], Bayelsa State, Nigeria with 72.24 [23].

The mean CI of this study (combined population) was $76.67 \pm 3.18$ which shows that the major head shapes among the North Indians are dolichocephalic and mesocephalic. Our finding was also lower than Singh and Purkit [17] study in India with $78.53 \pm 5.38$, Shah and Jadhav [20] study with 80.42, Mishra et al. [17], a study in Berelas of Central India was reported 77.79, study on Manipal population with 78.92 \pm 6.31 [19], a study in Port Harcourt, Nigeria with 79.80 [24]. But CI was more when compared to study in Tehran-Iran with 75 [21] and study by Eroje et al. [23], for Ogbia of Nigeria with 72.96. Hence, the present study's findings revealed that the sexual dimorphisms in cranial dimensions are pronounced best in mesocephalic form. The results of the present study agree with various other studies which compare anthropometric characteristics of females and males. Most of such writers have found the presence of sexual dimorphism in their respective studied samples. Oladipo et al. [25], on the facial measurements among chief ethnic groups in Nigeria where sexual dimorphism was observed in every ethnic group, studied with males having higher facial indices than females ( $p<0.05$ ). Studies were done by Maina et al. [13] and Raji and Garba [26], who confirm comparable works on craniofacial classifications of normal newborn and morphological assessment of face and head shapes, all in a sampled north-eastern Nigerian population.

The age, MCL, MCB, IZL, OL, and CI on applying the Pearson correlation we find the statistically significant association with each other $(\mathrm{p}<0.054)$; but statistically insignificant correlation was observed only in age with CI and age with IZL (Table 4). Dolichocephalic and brachycephalic type of skull was found more in 3160 years age, and mesocephalic type of skull was more in $\leqslant 30$ years age (Table 5). While dolichocephalic and mesocephalic types of the skull were found more in male subjects, and brachycephalic type of skull was more in female subjects (Table 6).

In our study, the dominant head shape type was dolichocephalic (47.2\%) followed by mesocephalic (30.4\%). This was similar to a study performed by Ahmed et al. [27], who found $58.5 \%$ of the Indian population was dolichocephalic. Dominant head type in this study was not similar to other studies in Nigeria by Akinbami [16], the study in central India by Yagain et al. [19], the study of the Igbo tribe of Nigeria by Oladipo and Olotu [22], and the study in Port Harcourt, Nigeria by Fawehinmi and coworkers [23]. This shows that there is a tendency toward dolichocephalic. Comparing the previous records of the CI with current work proves the tendency towards "mesocephalic" that is a confirmation of continuous growth of brain more in lateral direction [20] (Table 8). Also, in tropical zones, the form of the head is longer (i.e., dolichocephalic), but in the temperate zones, the head type is round (i.e., mesocephalic or brachycephalic) [28]. Since India is in both temperate and tropical zones partly, the present classification depicts a tendency to dolichocephalic from brachycephalic. 


\section{Cureus}

\begin{tabular}{|l|l|}
\hline Studies & Cephalic index (mean) \\
\hline Akinbami [16] & $76.86 \pm 2.54$ \\
Singh and Purkit [17] & $78.53 \pm 5.38$ \\
Paulinus et al. [15] & $75.95 \pm 4.09$ \\
\hline The present study (2020) & $76.67 \pm 3.18$ \\
\hline
\end{tabular}

TABLE 8: Cephalic Indices of different studies

\section{Limitations of the study}

Limited data on the craniofacial dimensions of the study population are a huge barrier in the precise estimation of the MCL and MCB. Also, this study is based on CT scans so there may be few variations in knowledge as no direct patient is involved.

\section{Recommendations of the study}

Further studies recommended on a gene variation basis are required to determine the specific genetic factors accountable for differences in cephalic indices among tribes, sexes, and races.

\section{Conclusions}

The $\mathrm{CI}$ is a useful and indispensable tool used for assessing skull shape in adults as well as in children, especially for pre-and postoperative correction of skull deformations. We observed that dolichocephaly (47.2\%) and mesocephaly (30.4\%) are the dominant shapes of the head among the North Indians. Parameters of sexual dimorphism in the cranial dimensions have been examined and established in the Northern Indian population in the city Lucknow. Knowledge of cranial parameters and cranial index is essential in evaluating age, gender, and racial differences in clinical applications and forensic applications.

\section{Additional Information \\ Disclosures}

Human subjects: Consent was obtained or waived by all participants in this study. Era's Lucknow Medical College and Hospital issued approval ERAMS9155. Animal subjects: All authors have confirmed that this study did not involve animal subjects or tissue. Conflicts of interest: In compliance with the ICMJE uniform disclosure form, all authors declare the following: Payment/services info: All authors have declared that no financial support was received from any organization for the submitted work. Financial relationships: All authors have declared that they have no financial relationships at present or within the previous three years with any organizations that might have an interest in the submitted work. Other relationships: All authors have declared that there are no other relationships or activities that could appear to have influenced the submitted work.

\section{References}

1. Anitha MR, Vijayanath V, Raju GM, Vijayamahantesh SN: Cephalic index of north Indian population . Anatomica Karnataka. 2011, 5:40-43.

2. Golalipour MJ, Haidari K, Jahanshahi M, Frahani MR: The shapes of head and face in normal male newborns in South-East of Caspian Sea (Iran-Gorgan). J Anat Soc India. 2003, 52:28-31.

3. Williams P, Dyson M, Dussak JE, Bannister LH, Berry MM, Collins P, Ferguson MW: Gray's anatomy. Skeletal System. Churchill Livingston, London; 1995. 607-12.

4. Cephalic index. (2011). Accessed: July 04, 2019: https://www.britannica.com/science/cephalic-index.

5. Nair SK, Anjankar VP, Singh S, Bindra M, Satpathy DK: The study of cephalic index of medical students of Central India. Asian J Biomed Pharm Sci. 2014, 4:48-50.

6. Sarver DM, Johnston MW: Video imaging: techniques for superimposition of cephalometric radiography and profile images. Int J Adult Orthodon Orthognath Surg. 1990, 5:241-8.

7. Sharma N, Rohatgi S, Puri P: Potential use of cranial morphology in identification of monozygotic twins: a preliminary study. J Indian Acad Forensic Med. 2020, 42:36-39. 10.5958/0974-0848.2020.00010.X

8. Elzaki MM, Ayad CE, Hassan HA, Abdalla EA: Anthropometric computed tomography study of certain craniofacial parameters: cephalic length and cranial width, nasal height, width and index of adult Sudanese. Glo Adv Res J Med Med Sci. 2015, 4:467-472.

9. Modi JP: A Text-book of Medical Jurisprudence and Toxicology . Butterworth-Heinemann, Oxford; 1920. 10.1016/C2013-0-08118-2

10. Aggrawal A: Textbook of Forensic Medicine and Toxicology . Avichal Publication Company, Delhi; 2014.

11. Gupta N, Bala N, Srivastava NN, Mittal K: Sonographic assessment of fetal cephalic index among the population of western up: a prospective observational study. Indian J Neonatal Med Res. 2020, 8:01-06. 
10.7860/IJNMR/2020/44485.2270

12. Oladipo GS, Fawehinmi HB, Suleiman YA: The study of nasal parameters (nasal height, width and nasal index) among the Yorubas of Nigeria. J Biol Anthropol. 2009, 3:1-19.

13. Maina MB, Shapu YC, Garba SH, Muhammad MA, Garba AM, Yaro AU, Omoniyi ON: Assessment of cranial capacity in a North-Eastern adult Nigerian Population. J Appl Sci. 2011, 11: 2662-5. 10.3923/jas.2011.2662.2665

14. Ekizoglu O, Hocaoglu E, Inci E, et al.: Assessment of sex in a modern Turkish population using cranial anthropometric parameters. Leg Med (Tokyo). 2016, 21:45-52. 10.1016/j.legalmed.2016.06.001

15. Paulinus SO, Mba EE, Ukpong EV, et al.: Anthropometric study of the cranial parameters using computed tomography (CT) scan to establish cephalic index of a sampled population in Calabar, Nigeria. Glob J Pure Appl Sci. 2019, 25:153-9. 10.4314/gipas.v25i2.4

16. Akinbami BO: Measurement of cephalic indices in older children and adolescents of a Nigerian population . Biomed Res Int. 2014, 2014:527473. 10.1155/2014/527473

17. Singh P, Purkit R: A cephalometric study among subcaste groups Dangi and Ahirwar of Khurai Block . Anthropol. 2006, 8:215-17.

18. Mishra M, Tiwari A, Naik DC: Study of cephalic index in Vindhya region of Madhya Pradesh . Int J Med Sci Public Health. 2014, 3:1464-1465. 10.5455/ijmsph.2014.120920141

19. Yagain VK, Pai SR, Kalthur SG, Chethan P, Hemalatha I: Study of cephalic index in Indian students . Int J Morphol. 2012, 30:125-129.

20. Shah GV, Jadhav HR: The study of cephalic index in students of Gujarat . J Anat Soc India. 2004, 53:25-26.

21. Golalipour MJ: The effect of ethnic factor on Cephalic Index in 17-20 years old females of North of Iran . Int J Morphol. 2006, 24:319-22. 10.4067/S0717-95022006000400004

22. Oladipo GS, Olotu J: Anthropometric comparison of cephalic indices between the Ijaw and Igbo tribes . Glob J Pure Appl Sci. 2006, 12:137-38. 10.4314/gjpas.v12i1.16578

23. Eroje MA, Fawehinmi HB, Jaja BN, Yaakor L: Cephalic index of Ogbia tribe of Bayesla state . Int J Morphol. 2010, 28:389-92.

24. Fawehinmi HB, Osunwoke AE, Ligha AE, Okoh PD: A comparative study on the cephalic indices of normal growing children and children with sickle cell anaemia in Port Harcourt. J Exp Clin Anat. 2008, 7:27-29. 10.4314/jeca.v7i1.48021

25. Oladipo GS, Uzomba GC, Alabi AS, Gbarayege BB: Craniofacial morphometric study of adult Ogoni people of Nigeria. J Appl Biotechnol Bioeng. 2018, 5:311-314.

26. Raji JM, Garba SH: Morphological evaluation of head and face shapes in northeastern Nigerian population . Aust J Basic Appl Sci. 2010, 4:2228-2241.

27. Ahmed S, Aghera BR, Sharma G, Sharma MK, Rathore MS: Cephalic index in population of district Jhalawar, Rajasthan according to food habit and it's significance. Int Arch BioMedClin Res. 2018, 4:56-58.

28. Bharati S, Som S, Bharati R, Vasulu TS: Climate and head form in India. Am J Hum Biol. 2001, 13:626-34. 10.1002/ajhb.1101 